\title{
DOMETI I GRANICE UTJECAJA PRAVA EU-A NA OPĆI DIO NACIONALNIH KAZNENIH PRAVA
}

Dr. sc. Igor Vuletić, docent

Pravni fakultet Sveučilišta u Osijeku
UDK: 343.2::061.1EU

Ur.: 4. ožujka 2016.

Pr.: 20. travnja 2016.

Pregledni znanstveni rad

\begin{abstract}
Sažetak
U ovom radu autor raspravlja o pitanju je li moguć, odnosno u kojoj mjeri je moguć utjecaj kaznenog prava Europske unije na nacionalna kaznena prava kada je u pitanju opći dio. Naime, tradicionalni instituti općeg dijela do sada su rijetko bili predmetom intervencija EU-a jer je osnovni cilj kaznenog prava EU-a postići ujednačeno inkriminiranje određenih kaznenih djela, što je materija posebnog dijela. Ipak, u dosadašnjim instrumentima i praksi europskih institucija zamijetni su fragmenti općeg dijela. Autor analizira dosadašnju europsku pravnu stečevinu u ovom području i prepoznaje te fragmente te ih nastoji uobličiti u jedinstvenu cjelinu. Na kraju iznosi svoje mišljenje o tome je li harmonizacija općega dijela realna mogućnost te u kojem će smjeru teći daljnje formiranje supranacionalnog općeg dijela kaznenog prava.
\end{abstract}

Ključne riječi: sankcije, nečinjenje, stadiji kaznenog djela, direktiva, okvirna odluka, harmonizacija, suverenost.

\section{1. $U V O D$}

Po svojoj pravnoj naravi, kazneno pravo predstavlja važan izraz državne suverenosti. Kao takvo, ono je uvijek prilagođeno socijalno-političkim uvjetima određene države pa stoga ne čudi da između različitih država postoje značajne razlike u kaznenopravnim sustavima. Primjerice, dok će neke države strogo braniti prostituciju i predviđati ju kao kazneno djelo, druge će ju dekriminalizirati i regulirati kao dopuštenu djelatnost. Isto vrijedi i kada je u pitanju uporaba lakih druga i sl. Navedeno se može primijeniti i na područje Europske unije, unutar koje egzistira dvadeset i osam različitih kaznenopravnih sustava.

Imajući u vidu različitost kaznenopravnih tradicija tih dvadeset i osam država članica EU-a, tvorci europskih pravila stavili su težište na uspostavljanje instrumentarija kojim će se postići harmonizacija kao konačan cilj EU-a kad 
je u pitanju kaznenopravna materija. Pritom je naglasak stavljen na specifične probleme posebnog dijela, poput subvencijskih prijevara, zaštite okoliša, suzbijanja organiziranog kriminala i sl.

No, čini se da je pitanje harmonizacije općeg dijela u dosadašnjem razvoju kaznenog prava EU-a ostalo uglavnom zanemareno. To ne treba čuditi jer opći dio u najvećoj mjeri odražava posebnosti svakoga pojedinog nacionalnog sustava. Ipak, upitno je može li se materija općeg dijela samo tako zanemariti, odnosno je li moguća učinkovita harmonizacija posebnog dijela, a da se pritom ne zadire i u opći dio. Naime, u literaturi je jasno izraženo stajalište da je važno unificirati i opći dio jer će se time postići trostruki učinak: olakšat će se provedba kaznenog prava EU-a, ostvarit će se učinkovitija borba protiv kriminala i omogućit će se jednak tretman okrivljenika u različitim državama. ${ }^{1}$

Ovaj rad bit će posvećen problemu harmonizacije općeg dijela. Taj je problem u hrvatskoj literaturi potpuno zapostavljen i znanstvene rasprave su uglavnom koncentrirane na različita pitanja iz područja europskoga kaznenog procesnog prava. U poredbenoj se literaturi, međutim, mogu naći mnoge rasprave o harmonizaciji općeg dijela kaznenog prava. Stoga ćemo u nastavku razraditi pitanje harmonizacije općeg dijela kao cjeline. Najprije ćemo ukratko prikazati normativni okvir harmonizacije prije i nakon Lisabonskog ugovora. Potom ćemo upozoriti na temeljnu razliku u poimanju pojma kaznenog djela između anglosaksonskog i kontinentalnog prava i pokušati ocijeniti predstavlja li ta razlika nepremostivu prepreku učinkovitoj harmonizaciji i unifikaciji. Nakon toga, prikazat ćemo dosadašnji utjecaj kaznenog prava EU-a na opći dio nacionalnih kaznenih prava. Zaključno, dat ćemo našu ocjenu o tome u kojem bi smjeru trebao ići budući razvoj ove problematike.

\section{NORMATIVNI OKVIR - PRIJE I NAKON LISABONA}

Nastojanja za povezivanjem radi učinkovite borbe protiv međunarodnog kriminala na prostoru koji danas nazivamo Europskom unijom datiraju još od 1975. godine. Tada je uspostavljen forum ministara pravosuđa i unutarnjih poslova poznat pod nazivom «TREVI» (engl. Terrorism, Radicalism, Extremism, Violence International), čija je zadaća bila unaprijediti pravosudnu suradnju u kaznenim stvarima te tako uzdići borbu protiv najopasnijih oblika kriminala na višu razinu. TREVI je označio početak višegodišnjeg razvoja nadnacionalnog mehanizma međunarodne pravne pomoći.

Prvi značajniji korak u pravnom normiranju ovakve suradnje učinjen je 1993. godine, kada je na snagu stupio Ugovor iz Maastrichta. Taj Ugovor ima povijesni značaj jer je njime uspostavljena Europska unija kao nadnacionalna organizacija $\mathrm{s}$ trostupnom strukturom. U kontekstu naših izlaganja važan je treći stup u koji

1 Usp. Klip, Towards a General Part of Criminal Law for the European Union u Klip (ur.), Substantive Criminal Law of the European Union, Maklu, 2011., str. 16 - 19. 
je pripadalo i područje kaznenog prava u širem smislu. ${ }^{2}$ Dok je u prva dva stupa intencija miješanja Unije u nacionalne sustave već tada bila otvorenije izražena, trećem stupu se, kao «posljednjoj brani državnog suvereniteta» ${ }^{3}$, pristupalo s izvijesnom dozom rezerve. Regulatorni instrumenti koje je predviđao Ugovor iz Maastrichta bili su sljedeći: zajednička stajališta, zajedničke akcije i konvencije. Ovi instrumenti vrijedili su za sva tri stupa. Sva tri instrumenta su se u praksi pokazala nedostatnima, prvenstveno jer su bili prespori. Primjerice, konvencije su pokrile dobar dio kaznenopravne materije i nametale su obvezu državama potpisnicama da usklade svoja zakonodavstva, ali su istodobno zahtijevale i dugotrajan proces ratifikacije i implementacije.

Zbog toga je Ugovor iz Amsterdama 1999. godine otišao korak dalje te je uveo novi instrument pravne regulacije - okvirne odluke. Okvirne odluke bile su namijenjene harmonizaciji nacionalnih prava i bile su primjenjive i na treći stup. One su uredile mnoga pravna pitanja. Na ovom mjestu možemo spomenuti okvirnu odluku o europskom uhidbenom nalogu, kao možda i najznačajniju iz ovoga područja. Isto tako, bilo je i različitih okvirnih odluka koje su regulirale pojedina kaznena djela (pranje novca, trgovinu ljudima i sl.). Ipak, i okvirne odluke su imale ograničen domet jer, jednako kao i prethodni instrumenti, nisu mogle imati izravni učinak na nacionalne sustave ni u kaznenopravnom ni u drugim pravnim područjima.

$\mathrm{U}$ tom smislu, revolucionarni zaokret postignut je stupanjem na snagu Ugovora iz Lisabona 2009. godine. On je ukinuo trostupnu arhitekturu Europske unije i uspostavio jedinstveni pravni poredak u koji je uklopio i odredbe o policijskoj i pravosudnoj suradnji u kaznenim stvarima. Novi Ugovor donio je i nove instrumente utjecaja: uredbe i direktive. Pritom, uredbe otklanjaju nedostatke dosadašnjih instrumenata jer imaju izravni učinak. Direktive nemaju izravni učinak odmah, ali ga stječu ukoliko bezuspješno protekne implementacijsko razdoblje u nekoj od država članica. Opisani režim i dalje ne vrijedi za kaznenopravno područje. Zbog njihove specifičnosti i osjetljivosti, na kaznenopravna pitanja će se primjenjivati samo direktive, ali one nikada neće moći imati izravni učinak. Naime, direktiva ima izravni učinak samo onda ukoliko regulira, tzv. vertikalni odnos u smislu odnosa u kojem država ima obvezu prema pojedincu. Ako pojedinac ima obvezu prema državi, tada je odnos obrnuto vertikalan i direktiva više ne može imati izravni učinak, a nacionalni sud ne smije primijenjivati eurokomforno tumačenje. U kaznenom pravu država nameće pojedincu kako se ne smije ponašati, što znači da je u pitanju obrnuto vertikalan odnos pa stoga nije moguća izravna

2 Kazneno pravo u širem smislu sastoji se iz kaznenog materijalnog prava, kaznenog procesnog prava i kaznenog izvršnog prava. Vidi Novoselec/Bojanić, Opći dio kaznenog prava, 4. izmijenjeno i dopunjeno izd., Pravni fakultet Sveučilišta u Zagrebu, 2013., str. 1.

3 Satzger, International and European Criminal Law, C. H. Beck - Hart - Nomos, 2012., § 5, rub. br. 6 . 
primjenjivost direktivi. ${ }^{4}$ Ovo je stajalište u više odluka izrazio i Europski sud. ${ }^{5}$ To, drugim riječima, znači da je u kaznenom pravu i dalje moguć samo neizravni utjecaj na države-članice kroz različite vrste sankcija u slučaju njihova odbijanja implementiranja određene direktive. Time je u određenoj mjeri relativizirana važnost direktiva pa se može postaviti i pitanje predstavlja li Lisabonski ugovor u biti definitivno odustajanje Unije da uspostavi jači utjecaj u području kaznenog prava. U literaturi se na to pitanje uglavnom odgovara niječno. ${ }^{6}$

$\mathrm{Na}$ ovom mjestu nećemo se upuštati u iscrpniju analizu relevantnih odredbi Lisabonskog ugovora jer bismo time prešli zadane granice našeg rada. Spomenut ćemo tek da je materiji kaznenog materijalnog prava posvećen članak 83 . Lisabonskog ugovora ${ }^{7}$, koji pruža pravnu osnovu donošenja direktiva u ovom području pa time i formiranja zajedničkog općeg i posebnog dijela kaznenog prava.

\section{KAMEN SPOTICANJA: DVA RAZLIČITA KONCEPTA KAZNENOG DJELA}

Pretpostavka svake rasprave o stvaranju supranacionalnog kaznenopravnog sustava, bilo u okviru Europske unije ili neke druge organizacije, jasno je određenje koncepta kaznenog djela na kojem će se takav supranacionalni sustav zasnivati. Dok se anglosaksonski sustav zasniva na kaznenom djelu kao jedinstvu objektivnog

4 Tako i Đurđević, Lisabonski ugovor: prekretnica u razvoju kaznenog prava u Europi, Hrvatski ljetopis za kazneno pravo i praksu (Zagreb), vol. 15, 2/2008, str. 1096.

5 V. npr. C-457/02 Antonio Niselli, para. 29; 80/86 Kolpinghuis Nijmegen, para. 13; C-168/95 Arcaro, para. 37.

6 Usp., npr. Summers/Schwarzenegger/Ege/Young, The Emergence of EU Criminal Law, Cyber crime and the Regulation of the Information Society, Hart Publishing, 2014., str. 280 283.

7 Čl. 83.:

(1) Europski parlament i Vijeće mogu direktivama donesenim sukladno redovnom zakonodavnom postupku utvrditi minimalna pravila o definiranju kaznenih djela i sankcija u područjima osobito teških kaznenih djela s prekograničnim učincima koji proizlaze iz prirode ili učinka takvih kaznenih djela ili iz posebne potrebe njihova zajedničkog suzbijanja. Ta su područja kriminala sljedeća: terorizam, trgovanje ljudima i seksualno iskorištavanje žena i djece, nezakonita trgovina drogom, nezakonita trgovina oružjem, pranje novca, korupcija, krivotvorenje sredstava plaćanja, računalni kriminal i organizirani kriminal.

(2) Ako se pokaže da je za osiguranje učinkovite provedbe politike Unije u području koje podliježe mjerama usklađivanja bitno približavanje kaznenih zakona i propisa država članica, direktivama se mogu utvrditi minimalna pravila za definiranje kaznenih djela i sankcija na dotičnom području. Te se direktive donose istim redovnim ili posebnim zakonodavnim postupkom koji se primjenjivao za donošenje mjera za usklađivanje o kojima je riječ, ne dovodeći u pitanje čl. 76.

(3) Ako član Vijeća smatra da bi nacrt direktive mogao utjecati na temeljne elemente njegova kaznenopravnog sustava, može zatražiti da se nacrt te direktive uputi Europskom vijeću. U tom se slučaju redovni zakonodavni postupak obustavlja. Nakon rasprave i u slučaju usuglašenja, Europsko vijeće u roku od četiri mjeseca od tog prekida vraća nacrt Vijeću koje će prekinuti obustavu redovnog zakonodavnog postupka. 
(actus reus) i subjektivnog (mens rea) elementa, kontinentalni sustavi uglavnom prihvaćaju mnogo kompleksniji i sofisticiraniji njemački model kaznenog djela kao jedinstva radnje, bića, protupravnosti i krivnje (njem. Handlung, Tatbestand, Rechtswidrigkeit, Schuld). ${ }^{8}$ Sukladno tome, i kaznenopravna dogmatika općeg dijela kaznenog prava u Njemačkoj i zemljama pod njenim utjecajem na znatno je višem stupnju razvoja od ostatka Europe. Osim toga, poimanje načela zakonitosti dijametralno je suprotno u anglosaksonskom i kontinentalnom pravu. Anglosaksonski pristup priznaje sudskim odlukama odgovarajuće razine snagu presedana koji tvore korpus pravnih pravila. Za razliku od toga, u kontinentalnim sustavima sudske odluke nisu formalan izvor prava i na njima se ne može temeljiti odluka suda u nekom drugom predmetu. Naposljetku, anglosaksonska legislativna tradicija favorizira kazuističku metodu reguliranja, zbog koje je kazneno pravo fragmentarizirano kroz više posebnih zakona. Naprotiv, na kontinentu je uobičajeno da je kaznenopravna materija u cijelosti obuhvaćena jedinstvenim kaznenim zakonima. ${ }^{9}$

Da spomenute razlike predstavljaju vrlo veliki problem moglo se jasno vidjeti u okolnostima nastanka Rimskog statuta Stalnog međunarodnog kaznenog suda. Tijekom diplomatske konferencije u Rimu 1998. godine raspravljalo se o tome hoće li se propisivanju kaznenih djela iz nadležnosti Suda pristupiti kazuističkom ili apstraktnom metodom. Na kraju je, pod utjecajem angloameričkih država prevladala kazuistička metoda. Jednako tako, mnoga rješenja nisu prihvaćena jer su delegati pojedinih država tvrdili da su protivna temeljnim načelima koja vrijede u njihovom pravu. Najspornija područja odnosila su se na materiju sudioništva, zabluda, nužne obrane i krajnje nužde, sankcija i sl. ${ }^{10}$

Nespojive razlike angloameričkog i kontinentalnog poimanja kaznenog materijalnog prava dolaze do izražaja najviše kroz opći dio. U kontinentalnim kaznenim zakonima općim dijelom dominiraju načelo zakonitosti i krivnje, uz jasno uspostavljen sustav temeljnih kaznenopravnih instituta. Za razliku od toga, angloamerički sustavi često će zanemariti spomenuta načela pa će odgovornost temeljiti na presedanima i hodati po rubu načela krivnje. Kao najbolji primjer za to može poslužiti angloamerički institut conspiracy, kod kojeg se odgovara i za one doprinose pojedinih sudionika koji bi u kontinentalnom poimanju predstavljali

8 Na ovom mjestu ipak valja upozoriti kako određeni broj hrvatskih autora ne prepoznaje biće kaznenog djela kao zaseban element pa govori o kaznenom djelu kao jedinstvu radnje, protupravnosti, krivnje i kažnjivosti. Usp. npr. Bačić, Kazneno pravo, opći dio, 5. izd., Informator, 1998., str. 108. Za kritiku ovoga stajališta, v. pobliže Novoselec/Bojanić, Opći dio kaznenog prava, 4., izmijenjeno i dopunjeno izd., Pravni fakultet Sveučilišta u Zagrebu, 2013., str. 117.

9 Ove razlike prvenstveno proizlaze iz različitog konceptiranja Ustava u ovim dvama sustavima te, općenito, iz različitoga shvaćanja pojma i uloge države. Dok se u kontinentalnoj Europi autoritet države shvaća kao jedini izvor prava, u angloameričkom konceptu prava su ljudima dana od Boga, a država je tu samo kao njihov regulator. Za više v. Fleiner, Common Law and Continental Law: Two Legal Systems (online), Fribourg, 2005., str. 5 - 7.

10 Iscrpnije v. Josipović u: Josipović/Krapac/Novoselec, Stalni međunarodni kazneni sud, Narodne novine, 2001., str. 67 i dalje. 
eksces. Da takvo rješenje nije prihvatljivo kontinentalnoj dogmatici, jasno je pokazala i bogata primjena vrlo spornog instituta zajedničkog zločinačkog pothvata u praksi Međunarodnog kaznenog suda za bivšu Jugoslaviju. Potonja figura proizašla je upravo iz angloameričkog instituta conspiracy.

Imajući sve rečeno u vidu, možemo zaključiti da bi inzistiranje na potpunoj unifikaciji općeg dijela kaznenog prava bio neostvariv ideal. Europsko kazneno pravo na trenutnom stupnju razvoja ne može se shvaćati u tradicionalnom smislu, kao skup pravnih pravila kojima se utvrđuju pretpostavke kažnjivosti i primjena sankcija počiniteljima kaznenih djela. Postoje prevelike razlike između pojedinih sustava, kao i jako izražena težnja svakog sustava da očuva svoj kaznenopravni identitet. Stoga razvijanje jedinstvenog (nadnacionalnog) koncepta kaznenog djela i kazne niti nije u srži europskog kaznenog prava. Naprotiv, ono se za sada sastoji iz fragmenata koje je Unija prepoznala kao najvažnije za opstanak i zajedničku sigurnost. Ti su fragmenti, kroz dosadašnje pravne instrumente Unije i praksu Europskog suda, uobličeni u svojevrstan supranacionalni pravni okvir te predstavljaju korpus europskog kaznenog prava. ${ }^{11} \mathrm{U}$ tom ćemo smislu u nastavku raspravljati o dijelovima europske pravne stečevine za koje držimo da se u ovom trenutku mogu karakterizirati kao fragmenti općega dijela europskog kaznenog prava. ${ }^{12}$

\section{FRAGMENTI HARMONIZACIJE OPĆEGA DIJELA U DOSADAŠNJEM RAZVOJU}

Fragmenti općega dijela o kojima ćemo govoriti u nastavku ovoga teksta plod su višegodišnjeg rada normativnih tijela Europske unije, koja su kroz različite okvirne odluke i direktive uspostavila određen korpus pravila. Jednako tako, ovi fragmenti proizlaze i iz mnogobrojnih odluka Europskog suda, koji je uspio stvoriti relevantnu praksu u ovom području. Dakako, i ta je praksa djelomična i ograničena samo na određena (najvažnija) područja općeg dijela. ${ }^{13}$

Prvi i daleko najrazrađeniji institut općega dijela kaznenog prava koji se navodi u spomenutim aktima je načelo zakonitosti. Ovim se načelom Europski sud bavio u nizu svojih odluka. Kao primjer možemo navesti odluku u predmetu Antonio Niselli. Tamo je Sud jasno naveo kako direktiva ne može sama po sebi i

11 Usp. Nuotio, European Criminal Law u Dubber/Hörnle, The Oxford Handbook of Criminal Law, Oxford University Press, 2014., str. 1120.

12 Zanimljivo je, međutim, spomenuti kako u literaturi postoje zagovornici stvaranja projekta European Model Penal Code po uzoru na American Model Penal Code. Usp. Dubber, The American Law Institute's Model Penal Code and European Criminal Law u Klip (ur.), Substantive Criminal Law of the European Union, Maklu, 2011., str. 209 - 226.

13 Za više o mogućnostima stvaranja općeg dijela europskog kaznenog prava kroz praksu Europskog suda v. npr. Löhmus, European Criminal Law: Can a general part be developed through case law? u: Klip (ur.), Substantive Criminal Law of the European Union, Maklu, 2011., str. $199-207$. 
bez implementacije u nacionalno zakonodavstvo biti temelj kaznene odgovornosti pojedinca. ${ }^{14}$ Još jasnije je to stajalište izraženo u odluci Kolpinghuis Nijmegen. Tamo se Sud pozvao na načela određenosti i zabrane retroaktiviteta, kao konkretizacijske parametre načela zakonitosti. ${ }^{15}$ Ova se načela ne smiju kršiti niti eurokonformnim tumačenjem, kojim su inače nacionalni sudovi u pravilu vezani. ${ }^{16} \mathrm{U}$ nekim drugim odlukama, Sud se pozvao na načelo obvezne primjene blažeg kaznenog zakona. ${ }^{17}$ Općenito je ovo načelo prihvaćeno u više sudskih odluka kao opće načelo prava Europske unije. ${ }^{18}$

Kao najsporniji aspekt ovoga načela u literaturi se ističe zahtjev za određenošću pravnih normi (nullum crimen sine lege certa). Postoji različitost u tumačenju ovoga načela u zemljama europskog kontinentalnog kaznenopravnog kruga, spram anglosaksonskih zemalja. Na kontinentu je ovo načelo, kao podoblik načela zakonitosti, naslovljeno na zakonodavca. Ono od njega traži da norme kaznenog prava kojima utvrđuje opise kaznenih djela propisuje što jasnije i preciznije. Isto vrijedi i za sankcije. S druge strane, u Engleskoj se Parlament smatra najvišim mogućim autoritetom koji ne treba biti ograničen ničim pa ni fundamentalnim načelima. Stoga se određenost odnosi prvenstveno na sudsku praksu i stvaranje presedanskih pravila kroz common law. Kada se govori o kaznenom pravu Unije, upozorava se da direktive nisu predviđene kao instrument koji je adresiran na pojedince. Naprotiv, one predstavljaju harmonizacijski instrument upućen zakonodavcima radi ujednačavanja minimalnih pravila na pravnom prostoru Unije. One stoga ne mogu imati isti onaj stupanj određenosti koji se očekuje od kaznenih zakona u državama članicama. Iz tog razloga, načelo određenosti u europskom kaznenom pravu podrazumijeva podjelu poslova između europskog i nacionalnih zakonodavaca na način da su potonji dužni implementirati direktivu s višim stupnjem određenosti. ${ }^{19}$ Ipak, možemo primijetiti da će tako shvaćeno načelo određenosti neminovno dovesti do različitih pretpostavki kaznene odgovornosti u pojedinim država i time do nejednakog položaja okrivljenika u kaznenom postupku.

14 C-457/02 Antonio Niselli, para. 29:

«...a directive cannot, of itself and independently of a national rule of law adopted by a Member State for its implementation, have the effect of determing or aggravating the liability in criminal law of persons who act in contravention of the provisions of that directive.»

15 Case 80/86 Kolpinghuis Nijmegen, para. 13:

«However, that obligation of the State is limited by the general principles of law which form part of Comunity law and in particular the principles of legal certanty and non-retroactivity. Therefore a directive cannot, of itself and independently of a national law adopted by a Member State for its implementation, have the effect of determing or aggravating the liability in criminal law...»

16 V. npr. spojene slučajeve C-74/95 i C-129/95, criminal proceedings against X, para. 24.

17 Npr. vidi C-387/02, C-391/02 i C403/02, criminal proceedings against Silvio Berlusconi, Sergio Adelchi, Marcelo Dell 'Utri i dr., para. 68.

18 Sud ovo stajalište jasno izražava, npr. u predmetu C-308/06, Intertanko and Others, para. 69.

19 Peristeridou, The principle of lex certa in national law and European perspectives u Klip (ur.), Substantive Criminal Law of the European Union, Maklu, 2011. str. 85 - 88. 
Nadalje, pravni instrumenti Unije uređuju pitanje primjene kaznenog zakona na situacije s obilježjem inozemnosti. Većina instrumenata utvrdila je teritorijalno načelo kao rukovodno u određivanju kaznene vlasti pojedine države članice. ${ }^{20}$ No, spominju se i ostala načela, poput načela zastave broda ${ }^{21}$, aktivnog personaliteta ${ }^{22}$, pasivnog personaliteta ${ }^{23}$ i slično.

Neki instrumenti bave se pitanjem oblika krivnje. Tako se uglavnom upućuje države da propišu kažnjivost namjernih oblika kaznenih djela. ${ }^{24}$ Nekada se traži propisivanje i nehajnih oblika, što i ne čudi s obzirom na to da su predmet interesa Unije samo najteža i najopasnija kaznena djela. ${ }^{25}$ Postojanje različitih oblika krivnje u kontinentalnom i engleskom pravu može predstavljati značajan problem u implementaciji te (opet) može dovesti do nejednakog tretmana okrivljenika na području Unije. Taj je problem već prepoznat u poredbenoj literaturi pa se mogu naći i konkretni prijedlozi za njegovo rješavanje. Tako Blomsma tvrdi da bi trebalo uspostaviti jedinstveni supranacionalni sustav u kojem bi postojala tri oblika krivnje: dolus, koji bi obuhvaćao sve oblike namjere, zatim recklessnes, koji bi sadržajno odgovarao hrvatskom svjesnom nehaju, i negligence ili culpa, koji bi sadržajno odgovarao hrvatskom nesvjesnom nehaju. ${ }^{26}$

Kazneno pravo Europske unije bavi se i sudjelovanjem više osoba u počinjenju kaznenog djela. Čini se da se pravo Unije priklanja dualističkom modelu jer, uz počiniteljstvo, spominje i druge oblike sudioništva poput poticanja, pomaganja i slično. ${ }^{27}$ Potreba za ujednačenom regulacijom materije sudioništva ističe se i u doktrinarnim raspravama kao jedan od prioriteta u bližoj budućnosti. Upozorava se da novi pojavni oblici kriminaliteta zahtijevaju promjenu pristupa kada je u pitanju sudjelovanje više osoba. Potrebno je razvijati koncepte koji će spriječiti da najodgovorniji izbjegnu kaznenu odgovornost. Zagovara se kažnjavanje «suštinske» odgovornosti (engl. substantial responsibility) za kazneno djelo. ${ }^{28} \mathrm{Mi}$ smatramo da jedno moguće rješenje ovog problema treba tražiti u Roxinovoj teoriji o posrednom počiniteljstvu korištenjem organiziranog aparata moći. Roxin je svoju tezu o počinitelju za pisaćim stolom (njem. Schreibtischtäter) izvorno zamislio kao instrument pravednog sankcioniranja naredbodavaca ubojstava prebjega iz bivšeg DDR-a. Takav počinitelj upravlja tzv. «aparatom moći» (njem. Machtapparat) dobro uhodanom organizacijom koja funkcionira po strogo hijerarhijskom načelu,

20 Npr. čl. 8. Okvirne odluke o trgovini drogom 2004/757/PUP, čl. 4. Zajedničkog stajališta 98/733/JHA o inkriminiranju sudjelovanja u zločinačkim organizacijama itd.

21 Čl. 9. st. 1. Okvirne odluke 2002/475 o suzbijanju terorizma.

22 Čl. 8. Okvirne odluke o trgovini drogom 2004/757/PUP.

23 Čl. 10. st. 2. Direktive 2011/36 o suzbijanju trgovanja ljudima.

24 Tako npr. Okvirna odluka 2008/841 o borbi protiv organiziranog kriminala govori o htijenju i znanju (engl. intent and knowledge).

25 Nehaj se navodi, primjerice, u Direktivi 2008/99 o kaznenopravnoj zaštiti okoliša.

26 Blomsma, Fault elements in EU criminal law: the case for recklessness u Klip (ur.), Substantive Criminal Law of the European Union, Maklu, 2011., str. 139 - 159.

27 Usp. npr. čl. 3. Okvirne odluke o trgovini drogom 2004/757/PUP.

28 Keiler, Towards a European Concept of participation in crime u Klip (ur.), Substantive Criminal Law of the European Union, Maklu, 2011., str. 196. 
pa je počinitelj siguran da će njegovi nalozi biti bespogovorno izvršeni. Stoga njegov doprinos ne treba kvalificirati kao poticateljski jer on u biti ima «vlast» nad neposrednim počiniteljima. ${ }^{29}$ Iako se Roxin, kao tvorac ovoga koncepta, načelno protivi njegovoj primjeni na slučajeve gospodarskog kriminala ${ }^{30}$, u suvremenoj njemačkoj literaturi postoje i drukčija stajališta. ${ }^{31}$

Nadalje, europska pravila spominju i još neke od klasičnih instituta općega dijela. Članak A (a) II. Zajedničkog stajališta 97/154 o sprječavanju trgovine ljudima i članak 5. st. 3. Okvirne odluke 2005/222 o napadima na informacijske sustave govore o pokušaju kaznenog djela. Europski sud je u jednoj svojoj odluci ${ }^{32}$ izričito naveo da se stranka mora izrijekom distancirati od kriminalne radnje i prijaviti je nadležnim vlastima. U suprotnom se ima smatrati sudionikom. Iz toga su vidljiva dva instituta općega dijela: supočiniteljstvo nečinjenjem i dobrovoljni odustanak od takvog supočiniteljstva aktivnom radnjom sprječavanja dovršenja kaznenog djela.

Konačno, različiti europski dokumenti spominju i neke vrste sankcija. Tu najčešće nije riječ o kaznenopravnim sankcijama, nego o sankcijama iz nekih drugih pravnih područja poput zaštite tržišnog natjecanja i slično. Sve sankcije koje se navode mogu se svesti na tri osnovne vrste, a to su globe, druge financijske mjere te mjere koje se sastoje u gubitku ili ograničavanju određenih prava. Pritom, nije uvijek jasna pravna priroda tih sankcija pa je državi ostavljeno da odluči hoće li ih regulirati kroz kazneno pravo ili će, poštujući načelo supsidijarnosti kaznenog prava, posegnuti za nekom drugom blažom pravnom granom. Prema vladajućem stajalištu u literaturi, one sankcije koje imaju kaznenopravni karakter nikada se ne mogu izravno primjenjivati pa čak ni onda kad je riječ o zaštiti pravnih dobara Unije koja su već pokrivena odgovarajućim bićima kaznenih djela u nacionalnim pravima. ${ }^{33}$

Svi prikazani pravni akti Europske unije jasno govore o postojanju fragmenata općeg dijela na supranacionalnoj razini. Ovo, dakako, nisu jedini primjeri. Razne druge okvirne odluke, zajednička stajališta i, u novije vrijeme, direktive sadrže pozivanje na tradicionalne institute općeg dijela. Još više takvih fragmenata može se naći u praksi Europskog suda. Na ovom mjestu se ipak nećemo upuštati u daljnju analizu tih akata jer bismo time prešli granice našeg rada. Do sada izneseni primjeri jasno ilustriraju začetke materije općega dijela u pravnim aktima Europske unije.

29 Za više v. Roxin, Strafrecht. Allgemeiner Teil, Band II, Besondere Erscheinungsformen der Straftat, Verlag C. H. Beck, München, 2003., § 25, rub. br. 105 - 112

30 On drži da se kod gospodarskog kriminala ne može raditi o organizacijama koje su «otuđene od pravnog sustava», kao i da u tim situacijama neposredni počinitelji nisu jednostavno zamjenjivi. Roxin, Strafrecht. Allgemeiner Teil, Band II, Besondere Erscheinungsformen der Straftat, (München: Verlag C. H. Beck, 2003.), § 25, 129 - 138.

31 V. npr. Brammsen/Apel, Anstiftung oder Täterschaft? «Organisationsherrschaft» in Wirtschaftsunternehmen, Zeitschrift für das Juristiche Studium, 3/2008, str. $257-258$.

32 Spojeni slučajevi C-189/02 P, C-202/02 P, C 205/02 P, C208/02 P i C 213/02 P, Dansk Rorindustri and Others v. Commission, para. 143.

33 Za više usp. Vogel u Sieber/Brüner/Satzger/v. Heintschel-Heinegg (ur.), Europäisches Strafrecht, C. H. Beck - Nomos, 2011., § 5, 3. Kapitel, rub. br. 2 - 3. 


\section{UMJESTO ZAKLJUČKA: KAMO IDE BUDUĆI RAZVOJ?}

Na prethodnim stranicama raspravljali smo o pitanju dometa i granica utjecaja europskog kaznenog prava na opći dio kaznenog prava država članica. Smatramo da je to pitanje vrlo važno, posebice nakon lisabonske reforme koja je ukinula podjelu Unije na tri stupa te tako uspostavila supranacionalne nadležnosti i na područje kaznenog prava. Usprkos važnosti ove teme, ona do sada u hrvatskoj literaturi nije bila sustavno raspravljana.

Na temelju iznesenih izlaganja, možemo zaključiti da unijsko pravo naglasak za sada stavlja na posebni dio kaznenog prava. To proizlazi i iz odredbi samog Lisabonskog ugovora - koji nabraja kaznena djela čija je inkriminacija od interesa za čitavo područje Europske unije - i iz sad već sadržaja mnogobrojnih direktivi koje su usmjerene na propisivanje i harmonizaciju određenih kaznenih djela. Isto vrijedi i za ranije instrumente, prvenstveno za okvirne odluke. No, jednako tako, iz ranije rasprave jasno proizlazi i zaključak da harmonizacija posebnoga dijela nije moguća bez ujednačavanja temeljnih načela općega dijela. Štoviše, učinkovita zaštita od najopasnijih oblika kriminala na području Unije nije zamisliva bez ujednačenog definiranja važnih instituta poput, primjerice, sudioništva, oblika krivnje, pokušaja kaznenog djela, zastare kaznenog progona, nečinjenja i slično. Opći i posebni dio se stalno isprepliću i predstavljaju jednu nerazdruživu cjelinu zbog čega ih je potrebno pravno tretirati na jedinstven način. Zbog toga smatramo da se utjecaj Unije na ujednačavanje općeg dijela u budućnosti mora pojačavati kako bi se smanjile razlike u sustavima. Time će se postići dvostruki učinak: smanjit će se prostor počiniteljima da izbjegnu kaznenu odgovornost, ali će se ujedno i poboljšati položaj okrivljenika u kaznenom postupku, jer će im se u svakoj državi članici suditi pod približno istim pretpostavkama kaznene odgovornosti.

Sljedeće važno pitanje je kako ostvariti takvo ujednačavanje. Naime, među pojedinim državama postoje velike razlike u načinu reguliranja općega dijela kaznenog prava. Temeljni instituti općega dijela tvore kaznenopravnu tradiciju pojedine zemlje pa će svaka država članica pružati otpor bilo kakvim promjenama koje nisu u skladu s njenom pravnom tradicijom. To posebno dolazi do izražaja kroz (nepremostivu) razliku između anglosaksonskog sustava kaznenog prava, kakav postoji u Engleskoj, i kontinentalnog sustava, koji egzistira u većini država članica Europske unije. No, i unutar kontinentalnog sustava postoje značajne razlike u pravnoj tradiciji. Stoga se na prvi pogled čini da je harmonizacija općeg dijela nastojanje koje je unaprijed osuđeno na propast. Mi smatramo da to ne mora biti tako ukoliko se odabere pravi pristup. Inzistiranje na stvaranju jedinstvenog supranacionalnog kaznenog zakona, po uzoru na poznati projekt Corpus Juris ili na američki Model Penal Code, odnosno na Rimski statut Međunarodnog kaznenog suda bilo bi promašeno. Države članice će uvijek pokazivati otpor prema objedinjavanju nacionalnih kaznenih sustava pod okrilje supranacionalnog jer se kazneno pravo smatra posljednjom branom državnog suvereniteta. Svaki pokušaj uspostavljanja nekog «nadzakona» u ovom području neminovno će biti tumačen kao 
pokušaj oduzimanja spomenutog suvereniteta. Iz tog razloga, put posrednog utjecaja putem obvezujućih direktiva, koji je odabrao Lisabonski ugovor, je jedini pravi i realno ostvarivi put. Ono na čemu još treba raditi je produbljivanje materije općeg dijela u direktivama, odnosno posvećivanje veće pažnje tradicionalnim institutima općeg dijela u kontekstu konkretnih kaznenih djela na koje se pojedina direktiva odnosi. Dosadašnji rezultati su još uvijek suviše fragmentarni i nepovezani. Kao dobar primjer za ono što predlažemo možemo spomenuti načelo zakonitosti. Kako smo ranije ilustrirali, mnogi europski akti i praksa Europskog suda inzistiraju na tom načelu. Time ono postaje neupitni dio jedinstvenih europskih pravnih načela. Takvu praksu treba uspostaviti i kod drugih važnih instituta, prvenstveno načela krivnje te sudioništva, jer su ti problemi najvažniji za učinkovitu primjenu kaznenog prava na raznolikom području Europske unije.

Naposljetku, moramo osobito naglasiti i vrlo važnu ulogu Europskog suda. Sud je u poziciji da autoritetom svojih odluka, također doprinosi formiranju i harmoniziranju općeg dijela. Prikazali smo više odluka u kojima su raspravljana pitanja koja po svojoj pravnoj naravi pripadaju u opći dio. Smatramo da bi se u budućnosti Sud još više trebao usredotočiti na takva pitanja.

Na kraju, možemo reći da europsko kazneno pravo na današnjem stupnju razvoja ima i opći dio. Taj je opći dio obilježen dvjema značajkama. S jedne strane, on je djelomičan jer regulira samo pojedine (najvažnije) institute i to samo $\mathrm{u}$ vrlo ograničenom opsegu. S druge strane, on je samo neizravno primjenjiv jer uvijek zahtijeva implementaciju u nacionalne sustave. Stoga je opći dio europskog kaznenog prava za sada još uvijek vrlo rudimentaran. Bez obzira na to, njegovo nedvojbeno postojanje i njegova nerazdruživa povezanost s posebnim dijelom kaznenog prava predstavljaju značajan čimbenik u razvoju europskog kaznenog prava prema dogmatski uobličenom sustavu pravnih pravila. Stoga harmonizaciju općega dijela, zajedno s harmonizacijom posebnoga dijela, u godinama koje dolaze treba intenzivirati. 


\section{Summary}

\section{SCOPE AND LIMITS OF THE IMPACT OF EU LAW ON THE GENERAL PART OF NATIONAL CRIMINAL LAWS}

In this paper, the author discusses the question of possibility of the impact of EU law on national criminal laws when it comes to general part. The traditional institutes of the general part have so far rarely been the subject of intervention by the EU because the main goal of EU criminal law is to achieve uniform criminalization of certain offenses, which is primarily the matter of a special part. However, in previous instruments and practices of the European institutions one can notice certain fragments of the general part. The author analyzes the current European acquis in this area and recognizes these fragments, and he tries to shape it into a unified whole. He gives his opinion whether harmonization of the general part is realistic possibility and in which direction will further formation of supranational general part of criminal law go.

Key words: sanctions, omissions, inchoate crimes, directive, franework decision, harmonization, sovereignity.

\section{Zusammenfassung}

\section{REICHWEITE UND GRENZEN DER EU-EINFLUSSRECHTE AUF DEN GEMEINTEIL DER NATIONALEN STRAFRECHTE}

In dieser Arbeit beschäftigt sich der Autor mit der Frage ob bzw. in welchem Maße der Einfluss des Strafrechtes der Europäischen Union auf nationale Strafrechte möglich ist, wenn es sich um den Gemeinteil handelt. Nämlich, die traditionellen Institute des Gemeinteils waren bisher selten der Gegenstand der Intervention seitens der EU, da der Grundziel des EU-Strafrechts einheitliches Inkriminieren der bestimmten Straftaten ist, was auch die Materie des besonderen Teils ist. Dennoch, sind in bisherigen Instrumenten und der Praxis der europäischen Institutionen die Fragmente des Gemeinteils ersichtlich. Der Autor analysiert den bisherige europäische Besitzstand in diesem Bereich, erkennt diese Fragmente und versucht sie in eine gleichförmige Einheit zu gestalten. Am Ende gibt er seine Meinung darüber, ob die Harmonisierung des Gemeinteils eine reale Möglichkeit ist und in welcher Richtung die weitere Formierung des zwischenstaatlichen Gemeinteils des Strafrechts gehen wird.

Schlüsselwörter: Sanktionen, Nichtstun, Straftatstadium, Direktive, Rahmenentscheidung, Harmonisierung, Souveränität. 


\section{Riassunto}

\section{PORTATA E LIMITI DELL'INFLUENZA DEL DIRITTO DELL'UE SULLA PARTE GENERALE DEI DIRITTI PENALI NAZIONALI}

Nel presente lavoro l'autore tratta della questione se sia possibile, ossia in quale misura sia possibile, l'influenza del diritto penale dell'Unione europea sui diritti penali nazionali allorquando si tratta della parte generale. Vale a dire, gli istituti tradizionali della parte generale fino ad ora raramente sono stati oggetto di interventi da parte dell'UE, poiché lo scopo principale del diritto penale dell'UE è quello di raggiungere un'incriminazione omogenea di determinati reati, il che costituisce materia della parte speciale del diritto penale. Tuttavia, negli strumenti e nella prassi delle istituzioni europee sono stati rilevati frammenti relativi alla parte generale. L'autore analizza l'acquis europeo in tale ambito e riconosce tali frammenti, cercando di forgiarli in un unico insieme. Alla fine espone il proprio pensiero circa il fatto se l'armonizzazione della parte generale sia una possibilità reale ed in che direzione andrà la futura creazione della parte generale sovranazionale del diritto penale.

Parole chiave: sanzioni, omissioni, fase del reato, direttiva, decisione di massima, armonizzazione, sovranità. 